\title{
RESPONSE OF FABA BEAN PLANTS TO INOCULATION WITH Rhizobium leguminosarium AND OTHER RHIZOBACTERIA UNDER THREE NITROGEN LEVES IN NEWLY RECLAIMED SOIL \\ El-Howeity, M. A. ${ }^{1^{\star}}$; A. A. Abdalla ${ }^{1^{\star *}}$; Hanaa A. Abo-Kora ${ }^{2 \star}$ and M. M.El-Shinnawi ${ }^{3 *}$ \\ 1- Environmental Studies and Research Institute (ESRI), Minufiya University, Sadat City, Egypt. \\ ( ${ }^{\star}$ Soil Microbiology and ${ }^{* \star}$ Crop Science) \\ 2- Soils, Water and Environ. Res. Inst., Agric. Res. Center, Giza, Egypt. \\ 3- Dept. Soil Sci., Fac. Agric., Minufiya University, Shibin Elkom, Minufiya, Egypt.
}

\begin{abstract}
A field experiment was conducted twice at the farm of the Environmental Studies and Research Institute, Minufiya University, Sadat City (Minufiya Governorate), during the two successive winter seasons of 2006/2007 and 2007/2008 to study the response of faba bean (Vicia faba L. cv. Giza 461 ) to inoculation with Rhizobium leguminosarium individually or mixed with rhizobacteria known to produce plant growth- promoting substances (PGPR), i.e., Azospirillum brasilense, Bacillus megaterium or Bacillus polymyxa as co inoculation under three levels of mineral nitrogen fertilizer ( $0,20,40 \mathrm{~kg} \mathrm{~N} / \mathrm{fed}$ ), in a newly reclaimed desert (sandy soil).

Results showed that nodulation, plant growth parameters and bacterial activities in soil, varied depending on nitrogen dose and introduced bacteria. Co-inoculation with Rhizobium and PGPR resulted in significant increases in number and dry weight of root nodules, as well as nitrogenase activity of the root system as compared with the single inoculation with Rhizobium alone or control (un-inoculated plants). Mixed inoculation improved bacterial activities in rhizosphere soil, dehydrogenase, and phosphatases (acid and alkaline) enzymes and total bacterial count, compared to the single inoculation. In respect to nitrogen fertilizer, the highest rate applied( $40 \mathrm{~kg} \mathrm{~N}$ /fed.) gave the maximum value of bacterial activities, as compared with the other doses, except nitrogenase activity, which was favored with the lower N dose $(20 \mathrm{~kg})$.

The parameters of faba bean growth, seed yield and its attributes were generally promoted with the applied treatments, i.e., the biofertilizer significantly enhanced plant growth rate and parameters at $40 \mathrm{D}$ and 85 days age. Mixed inoculation (R.I.+ B. polymyxa) produced the highest values of plant height, shoot and root dry weights. The same treatment exhibited the greatest number of branches, number of pods, number of seeds / pod, seed index and seed yield /plant, and consequently highest seed yield /fed ,e.g., average increase in yield /fed. was $(67.45 \% \& 63.62 \%)$ for the two seasons, respectively. No significant differences could be detected between the two doses of nitrogen fertilizer (20 and $40 \mathrm{~kg} \mathrm{~N} / \mathrm{fed}$.) in most studied traits, except seed yield per plant and per fed. Inoculation with R.I. + B.megaterium or B. polymyxa combined with $40 \mathrm{~kg} \mathrm{~N} /$ fed. resulted in the highest values of most studied traits, except the nitrogenase activity, which was higher with $20 \mathrm{~kg} \mathrm{~N} / \mathrm{fed}$.
\end{abstract}

Keywords: Beneficial rhizobacteria, legumes, Rhizobium leguminosurm, nitrogen fertilization, sandy Soil. 


\section{INTRODUCTION}

Co-inoculation of legumes with rhizobia and rhizobacteria producing plant growth- promoting substances (PGPR) has received increasing attention in recent years. One of the most studied PGPR in relation to its interaction with the bacterial genus Rhizobium are those belonging to the genera Azospirillum and Azospirilla, they are free-living $\mathrm{N}_{2}$-fixing rhizobacteria which, live in close association with plants and are capable of increasing the yield of important crops grown on various soils and climatic regions. The reviewed data from field inoculation experiments showed statistically significant increases in yield on the order of $5-30 \%$ in $60-70 \%$ of published reports (Okon and Labandera-Gonzalez, 1994). The benefits observed following inoculation with Azospirillum were mainly attributed to improved root development and enhanced water and mineral uptake. Available evidence indicated that secretion of plant-growth promoting substances by bacteria was at least partly responsible for those effects (Okon and Vanderleyden, 1997). Indirect mechanisms used by PGPR include antibiotic protection against pathogenic bacteria, reduction of iron available to phytopathgens in the rhizosphere, synthesis of fungal cell wall- lysing enzymes, and competition with detrimental microorganisms for sites on plant roots. Direct mechanisms of plant growth by PGPR include the provision of bio-available phosphorus for plant uptake, nitrogen fixation for plant use, sequestration of iron for plants by siderophores, production of plant hormones like auxins, cytokinins and gibberellins and lowering of plant ethylene levels (Glick, 1995; Glick et al.,1999). Co-inoculation of several legumes with Azospirillum, Azotobacter, Bacillus and Rhizobium, or inoculation with Azospirillum or Azotobacter, alone in the case of naturally-nodulated legumes, was shown to benefit plant growth in the greenhouse and in the field (Burdman et al., 1998). The increase in dry-matter production and nitrogen content of dually inoculated plants might be attributed to earlier and enhanced nodulation, higher $\mathrm{N}_{2}$-fixation rates and a general improvement of root development (Okon and Itzigsohn, 1995). Dual inoculation with Rhizobium and Azospirillum or Azotobacter could either stimulate or inhibit nodule formation and growth in a given symbiotic system, depending on the concentrations and timing of inoculation, besides improving the microbiological activity in the rhizosphere (Kohler et al., 2007). Also, Cassan et al. (2008) found that single and combined inoculation with Azospirillum and /or Bradyrhizobium increased significantly shoot length and shoot and root dry weights of corn and nodulation of soybean.

Faba bean (Vicia faba), as the most important food legume has a potential necessity for Egyptian people. The national faba bean cultivated area over the last five years is 131.000 hectare, with an average productivity of $2.86 \mathrm{t} / \mathrm{ha}$. Faba bean production in Egypt is still limited and fails to face the local increasing consumption of the crop. So, increasing crop production is one of the major targets of the agricultural policy and can be achieved by both increasing the cultivated area and its productivity. 
The objective of this study is to evaluate the response of Egyptian faba bean cultivar to inoculation with Rhizobum leguminosurm alone or in combination with either Bacillus polymyxa, or Azospirillum brasilense or Bacillus megaterium under the effect of varying levels of mineral nitrogen on nodulation, plant growth and bacterial activities in rhizosphere soil and yield of faba bean crop.

\section{MATERIALS AND METHODS}

Field experiments were carried out at the farm of the Environmental Studies and Res. Institute, Minufiya Univ. (Sadat City Minufiya Governorate), Egypt, where the soil is sandy (newly reclaimed desert), in two successive growth seasons, i.e. 2006/2007 and 2007/2008. Some physical and chemical properties of the experimental soil were determined according to Page et al.,(1982)and their data are presented in Table(1a,b).

Table (1): Analytical data of the experimental soil (A):Physical properties

\begin{tabular}{|c|c|c|c|c|c|}
\hline $\begin{array}{c}\mathrm{CaCO}_{3} \\
(\%)\end{array}$ & $\begin{array}{c}\text { Organic matter } \\
(\%)\end{array}$ & \multicolumn{2}{|c|}{ Particle size distr., (\%) } & \multirow{2}{*}{$\begin{array}{c}\text { Texture } \\
\text { class }\end{array}$} \\
\cline { 3 - 5 } & & Sand & Silt & Clay & Sandy \\
\hline 1.9 & 0.3 & 88.6 & 4.8 & 6.6 & Sand \\
\hline
\end{tabular}

(B): Chemical Properties

\begin{tabular}{|c|c|c|c|c|c|c|c|c|c|}
\hline \multirow{2}{*}{$\mathbf{P H}^{*}$} & \multirow{2}{*}{$\mathrm{EC}^{\star *}$} & \multicolumn{3}{|c|}{ Soluble cations (meq/L) } & \multicolumn{4}{|c|}{ Soluble anions (meq/L) } \\
\cline { 3 - 9 } & dS. $\mathrm{m}^{-1}$ & $\mathbf{C a}^{++}$ & $\mathbf{M g}^{++}$ & $\mathrm{K}^{+}$ & $\mathbf{N a}^{+}$ & $\mathbf{C O}_{3}^{--}$ & $\mathbf{H C O}_{3}{ }^{-}$ & $\mathbf{C l}^{-}$ & $\mathbf{S O}_{4}^{--}$ \\
\hline 7.63 & 1.82 & 0.36 & 0.32 & 0.14 & 0.56 & - & 0.41 & 0.36 & 0.61 \\
\hline
\end{tabular}

${ }^{*}$ In the 1:2.5 Soil: water suspension. ${ }^{* *}$ In the soil paste extract.

\section{Bacterial strains:}

Strains of Rhizobum leguminosurm, Bacillus polymyxa, Bacillus megaterium and Azospirillum brasilense were obtained from Soils, Water and Environment Res. Inst., ARC, Giza,. Azotobacter was pre-cultured in a modified Ashby's medium (Hegazi and Niemela ,1976). The bacterial strains were grown in a nutrient broth liquid medium for 2 days at $30^{\circ} \mathrm{C}$, Cultures were then centrifuged at $1000 \mathrm{rpm}$. for $30 \mathrm{~min}$ at $10^{\circ} \mathrm{C}$. The sediment was re-suspended in $5 \mathrm{ml}$ sterilized $0.8 \% \mathrm{KCl}(\mathrm{w} / \mathrm{v})$. Bacterial suspension was again shacked for $5 \mathrm{~min}$. This material was considered as an inoculum

Agricultural Practices:

Prior to cultivation the manured area was divided into plots, each of $13.5 \mathrm{~m}^{2}$ including 6 rows $3 \mathrm{~m}$ in length and $0.75 \mathrm{~m}$ in width, Faba bean (Vicia faba) variety 461 seeds were planted on November 1 and 5 in 2006 and 2007, two respectively, at per hill and $20 \mathrm{~cm}$ apart on rows after inoculation with the assigned bacterial agents. Drip irrigation took place immediately. Amounts of nitrogen fertilizer were added as ammonium sulfate $(20.6 \% \mathrm{~N})$ at three levels, i.e., $0,20 \& 40 \mathrm{~kg} \mathrm{~N} / \mathrm{fed}$. Each dose was applied at three equal additions 18 days after sowing and ten days intervals. Potassium in the form of potassium sulfate $\left(48 \% \mathrm{~K}_{2} \mathrm{O}\right)$ and phosphorus as calcium supper 
phosphate $\left(15.5 \% \mathrm{P}_{2} \mathrm{O}_{5}\right)$ were added as recommended by the Egyptian Ministry of Agriculture at soil preparation.

Split plot design with four replications was used, where the levels of nitrogen were allocated in the main plots and the biofertilizer treatments were distributed in the sub plots. The experimental area had been under ordinary cultivation practices along both seasons.

Plant growth criteria, namely, plant height, shoot dry weight and root dry weight, were determined at 40 and 85 days, as well as number of root nodules, dry weight of nodules, nitrogenase activity, dehydrogenase, acid phosphatase and alkaline phosphatase were determined in rhizosphere soil at 40 and 75 days after sowing. Crop growth rate was calculated based on plant height, shoot and root dry weights as averages of the two seasons according to the following equation :-

$\mathrm{GGR}=(\mathrm{W} 2-\mathrm{W} 1) \times(1 / \mathrm{Ga}) /(\mathrm{T} 2-\mathrm{T} 1) \quad \mathrm{g} / \mathrm{m}^{2} /$ day

Were calculated for dry weight / plant according to the above mentioned equation where $\mathrm{W} 1$ and $\mathrm{W} 2$ = total dry weight / plant $(\mathrm{g})$ at $\mathrm{T} 1$ and $\mathrm{T} 2$ date of sampling, respectively. Whereas, $\mathrm{Ga}=$ ground area / plant.

\section{Assay of Enzyme Activities and Bacterial counts in Soil:}

Activities of the enzymes under study were determined according to the following methods:

- Dehydrogenase: colourimetrically, for the 2,3,5- triphenyl formazan (TPF) produced from the reduction of 2,3,5- triphenyl tetrazolium chloride (TTC), using acetone for extraction.....(Thalmann.,1967).

- Nitrogenase: by means of gas liquid chromatograph for ethylene produced from the reduction of acetylene....(Hardy et al., 1973).

- Phosphatases: colorimetrically, using a modified universal buffer (MUB) at $\mathrm{pH} 6.5$ for acid phosphatase and at $\mathrm{pH} 11$ for alkaline phosphatase ... (Tabatabai, 1982).

-Total bacterial numbers were determined using agar plate technique (Difco Manual, 1985).

At maturity, a sample of five guarded plants were uprooted to measure number of branches, number of pods, number of seeds /pod, seed index (100 seed weight) and seed yield /plant, then the four inner rows were harvested to calculate seed yield /fed. Analyses of variance were computed according to Gomez and Gomez (1984) using the least significant difference at 0.05 level, to compare the differences among means.

\section{RESULTS AND DISCUSSION}

\section{Nodulation Status of Faba Bean and Nitrogenase Activity:}

Data in Table (2 a \& b) showed that nodules number, dry weight of nodules and nitrogenase activity in both successive seasons, increased significantly due to the co-inoculation with Rhizobium leguminosarum plus Azospirillum brasilense, Bacillus megaterium or Bacillus polymyxa, as compared with the plants inoculated with Rhizobium leguminosarum alone or the un-inoculated plants on both $45^{\text {th }}$ and $70^{\text {th }}$ day after sowing (DAS). 
Nitrogen fertilizer improved nodulation status. Increases in nodules number with Rhizobium leguminosarum reached (74.77 and $32.71 \%)$ above the uninoculated plants at $45^{\text {th }}$ and $70^{\text {th }}$ DAS, respectively. These increases were more significant by using the mixed inoculation. Increases with $R$. leguminosarum plus Azospirillum brasilense reached (97.56 and $112.81 \%$ ) and with $R$. leguminosarum plus Bacillus megaterium were (115.27 and $124.62 \%$ ) and with $R$. leguminosarum plus Bacillus polymyxa reached $(101.36$ and $117.31 \%)$ at $45^{\text {th }}$ and $70^{\text {th }}$ DAS , respectively. Likewise, dry weight of nodules was increased with such inoculations. Rhizobium leguminosarum gave increases reached (26.77 and $18.58 \%)$ above the uninoculated plants on $45^{\text {th }}$ and $70^{\text {th }}$ DAS, respectively. Co-inoculation with Azospirillum brasilense gave (29.5 and $23.78 \%$ ) and Bacillus megaterium (33.28 and $21.01 \%$ ) and Bacillus polymyxa (31.82 and 21.67\%) above the control at $45^{\text {th }}$ and $70^{\text {th }}$ DAS, respectively. Nitrogenase enzyme activity had positively responded to the co-inoculation through its higher values, compared to those obtained by $R$. leguminosarum alone (Table2 a \& b). The highest $\mathrm{N}_{2}$-ase activity levels were recorded at the $70^{\text {th }}$ DAS compared to $45^{\text {th }}$ DAS. Increases in such enzyme activity above the control reached (154.8 and $410.48 \%$ ) with $R$. leguminosarum at both $45^{\text {th }}$ and $70^{\text {th }}$ DAS, respectively. Co-inoculation were superior in enhancing of $\mathrm{N}_{2}$-ase activity, when gave (447.89 and $707.58 \%)$ above the control by using $R$. leguminosarum plus $A$. brasilense at $45^{\text {th }}$ and $70^{\text {th }}$ DAS, respectively. The increases recorded due to the use of the mixed inoculum of $R$. leguminosarum plus B. megaterium were 311.71 and $537.16 \%$ ) above the control at $45^{\text {th }}$ and $70^{\text {th }}$ DAS, where as they were $(439.78$ and $656.86 \%)$ with $R$. leguminosarum plus $B$. polymyxa. Increases occurred upon using the coinoculation was $(115.03,61.57$ and $11.84 \%)$ above $R$. leguminosarum alone at $45^{\text {th }}$ DAS and $(58.19,24.81$ and $48.26 \%)$ at $70^{\text {th }}$ DAS with mixed Azospirillum brasilense, B. megaterium or B. polymyxa, respectively. Results in Table ( 2 a \& b) revealed that the highest values of number and weight of root nodules and $\mathrm{N}_{2}$-ase activity were attained with the co-inoculation, as compared with the single inoculation. Enhancement of nodulation status is actually due to root proliferation and thus boosting the $\mathrm{N}_{2}$-ase activity. Plazinski and Rolfe (1985) suggested that, rhizobacteria could stimulate additional infection sites that were later occupied by rhizobia. Rodelas et al. (1999) suggested that the increase resulted in a higher accumulation of $\mathrm{N}$ per plant. While concentration of such nutrient $(\mathrm{N} \%)$ in plant tissues remained similar to that found in the control plants, suggesting that the entire additional $\mathrm{N}$ absorbed was used to aid plant growth and development. The distribution of $\mathrm{N}$ between plant parts was slightly modified by some combined inoculation treatments. Such results indicate that several PGPR such as $A$. brasilense, $B$. megaterium and $B$. polymyxa used in this study exerted significant effects on $R$. leguminosarum symbiosis, which were only observed when this combination of microbial strains was used. Such promotion of nodulation and $\mathrm{N}_{2}$-ase activity in many legume species has been confirmed by many investigators (Rodelas et al., 1996 and 1999 , Abdel-Wahab and Said, 2004 and El-Howeity, 2004 and 2008). 
El-Howeity, M. A. et al.

2 
J. Agric. Sci. Mansoura Univ., 34 (6), June, 2009

2 


\section{Enzyme Activities in Rhizosphere Soil \\ A) Dehydrogenase activity (DA):}

Dehydrogenase activity (DA) is frequently used as a measurement of the overall microbial activity in soil. Changes in DA during both seasons of the different treatments are presented in Table ( $3 a \& b)$. Results showed that DA increased by time, application $\mathrm{N}$-fertilization and inoculation with $\boldsymbol{R}$. leguminosarum individually or mixed with $A$. brasilense or $B$. megaterium or $B$. polymyxa as co inoculation. Data showed that inoculation with $R$. leguminosarum alone increased DA up to ( 88.27 and $53.18 \%$ ) over the control at $45^{\text {th }}$ and $70^{\text {th }}$ DAS, respectively. However, these increases were more pronounced with the co-inoculation. Increases with $A$. brasilense reached (103.25 and $79.83 \%$ ) and with $B$. megaterium up to (101.79 and $69.32 \%)$ and with B. polymyxa were (115.31 and $95.31 \%)$ at $45^{\text {th }}$ and $70^{\text {th }}$ DAS, respectively. Dehydrogenases catalyze the electron transfer yielding energy required for the anabolic processes of various microorganisms inhabiting the soil. Through such reactions, the energy source, or electron donor, is converted to a simpler form that could be utilized by other organisms (plants and microbes). Hence, such enzymes are not only responsible for oxidation-reduction processes, but are also involved in the recycling of elements in soil for the benefit of both macro- and micro flora (Burns, 1982).

\section{B) Phosphatase activity (PA)" acid and alkaline phosphatases":}

Phosphatases are the biocatalysts that involved in the liberation of mineral phosphorus from its organic sources for the use of growing plants. Table ( $3 a$ \& b) declared that the mixed inoculation gave higher increases reached with $A$. brasilense up to (173.8 and $124.53 \%)$ and with $B$. megaterium (235.81 and $186.66 \%$ ) and with B. polymyxa (180.51 and $130.77 \%)$ at $45^{\text {th }}$ and $70^{\text {th }}$ DAS, respectively. The same trend was found for PA with $\mathrm{N}$ - fertilization and inoculation with $R$. leguminosarum alone or mixed with PGPR improved the activity of such enzyme at both detection times. Increases with $R$. leguminosarum alone were $(56.39$ and $63.04 \%)$ over the control at $45^{\text {th }}$ and $70^{\text {th }}$ DAS, respectively. However, the co-inoculation raised the activity of PA (both acid and alkaline), with A. brasilense to (167.83 and $109.62 \%$ ) and with B. megaterium ( 236.25 and $128.81 \%$ ) and with $B$. polymyxa (97.39 and $112.89 \%)$ at $45^{\text {th }}$ and 70 th DAS, respectively. Inoculation of faba bean with $R$. leguminosarum plus PGPR simulated the PA in rhizosphere soil. This may be due to the ability of PGPR in utilizing some organic compounds as carbon and energy sources and thus produce organic acids, which solubilizing insoluble inorganic phosphates. Richardson (2001) found that, solubilization of $P$ in the rhizosphere is the most common mode of action implicated by PGPR that increase nutrient availability to host plants. Dobbelaera et al. (2003) suggested that, PGPR stimulate plant growth by facilitating the uptake of minerals $\mathrm{N}, \mathrm{P}$ and $\mathrm{K}\left(\mathrm{NO}_{3}^{-}, \mathrm{H}_{2} \mathrm{PO}_{4}^{-}, \mathrm{K}+\right)$ and microelements by plants, however, there was some controversy regarding to the mechanisms that PGPR employ in the uptake of minerals, due to a general increase in the volume and root system, as reflected by increased root number, thickness and length. 
J. Agric. Sci. Mansoura Univ., 34 (6), June, 2009

3 
El-Howeity, M. A. et al.

3 
The enhanced phosphatase activity may help the plant to mobilize $P$ and thereby increases the biomass production (Tarafdar and Gharu, 2006). Increases observed for the activities of dehydrogenase, acid and alkaline phosphatases and nitrogenase may be related mainly due to increase in rhizosphere microbial population as a consequence of the inoculation treatments ( Aseri and Tarafdar, 2006).

Total Bacterial Numbers:

Total bacterial numbers in the rhizosphere soil, of faba bean plants, as affected by $\mathrm{N}$-fertilization and inoculation with $R$. leguminosarum individually or with Azospirillum spp. or Bacillus spp. are recorded in Table (4). Data revealed that, addition of $\mathrm{N}$-fertilizer and bacterial inoculation led to significant increases in total bacterial counts in the rhizosphere soil of bean plants. Increases occurred with $R$. leguminosarum were (20.61 and $22.33 \%)$ at 45 and 70 DAS, respectively.

Table (4): Effect of rhizobacteria and nitrogen fertilization on total bacterial count in rhizosphere soil of faba bean plants in both seasons

\begin{tabular}{|c|c|c|c|c|c|c|c|c|c|}
\hline \multirow{2}{*}{\multicolumn{2}{|c|}{ Treatment }} & \multicolumn{3}{|c|}{ Total count at 45 DAS } & \multicolumn{5}{|c|}{ Total count at 70 DAS $^{\star}$} \\
\hline & & $\begin{array}{c}0 \\
\mathrm{kgN} / \\
\text { fed. }\end{array}$ & $\begin{array}{c}20 \\
\mathrm{kgN} / \mathrm{fed} .\end{array}$ & $\begin{array}{c}40 \\
\mathrm{kgN} / \mathrm{fed}\end{array}$ & mean & $\begin{array}{c}0 \mathrm{kgN} / \\
\text { fed. }\end{array}$ & $\begin{array}{c}20 \\
\mathrm{kgN} / \mathrm{fed} .\end{array}$ & $\begin{array}{c}40 \\
\mathrm{kgN} / \\
\text { fed. }\end{array}$ & mean \\
\hline \multicolumn{10}{|c|}{ First Season } \\
\hline \multicolumn{2}{|c|}{ Control } & 5.54 & 5.71 & 5.8 & 5.68 & 5.74 & 5.93 & 5.94 & 5.87 \\
\hline \multicolumn{2}{|c|}{ R.legminoserium } & 6.83 & 7.1 & 7.37 & 7.10 & 6.81 & 7.14 & 7.47 & 7.14 \\
\hline \multicolumn{2}{|c|}{ R.I.+Azosprillum } & 7.03 & 7.55 & 7.78 & 7.45 & 6.92 & 7.32 & 7.92 & 7.39 \\
\hline \multicolumn{2}{|c|}{ RI.+B.megaterium } & 6.76 & 7.1 & 7.91 & 7.26 & 6.77 & 7.29 & 7.94 & 7.33 \\
\hline \multicolumn{2}{|c|}{ R.I.+B.Polymyxa } & 6.89 & 7.23 & 7.92 & 7.35 & 7.07 & 7.48 & 7.94 & 7.50 \\
\hline \multicolumn{2}{|c|}{ Mean } & 6.61 & 6.94 & 7.36 & 6.97 & 6.66 & 7.03 & 7.44 & 7.04 \\
\hline \multirow{3}{*}{$\begin{array}{l}\text { LSD, } \\
\text { at } 0.05\end{array}$} & $\mathbf{N}$ & \multicolumn{4}{|c|}{0.42} & \multicolumn{4}{|c|}{0.38} \\
\hline & Bio & \multicolumn{4}{|c|}{1.03} & \multicolumn{4}{|c|}{1.16} \\
\hline & $\mathbf{N} \times$ Bio & \multicolumn{4}{|c|}{1.12} & \multicolumn{4}{|c|}{1.32} \\
\hline \multicolumn{10}{|c|}{ Second season } \\
\hline \multicolumn{2}{|c|}{ Control } & 5.05 & 5.7 & 5.83 & 5.53 & 5.63 & 5.73 & 5.97 & 5.78 \\
\hline \multicolumn{2}{|c|}{ R.legminoserium } & 6.33 & 6.5 & 6.47 & 6.43 & 7.04 & 7.15 & 7.13 & 7.11 \\
\hline \multicolumn{2}{|c|}{ R.I.+Azosprillum } & 6.4 & 6.96 & 7.43 & 6.93 & 7.3 & 7.9 & 7.89 & 7.70 \\
\hline \multicolumn{2}{|c|}{ R.I.+B.megaterium } & 7.3 & 7.5 & 7.94 & 7.58 & 7.6 & 8 & 8.18 & 7.93 \\
\hline \multicolumn{2}{|c|}{ RI..+B.Polymyxa } & 7.55 & 7.66 & 7.99 & 7.73 & 7.74 & 8.04 & 8.23 & 8.00 \\
\hline \multicolumn{2}{|c|}{ Mean } & 6.53 & 6.86 & 7.13 & 6.84 & 7.06 & 7.36 & 7.48 & 7.30 \\
\hline \multirow{3}{*}{$\begin{array}{l}\text { LSD, } \\
\text { at } 0.05\end{array}$} & $\mathbf{N}$ & \multicolumn{4}{|c|}{0.61} & \multicolumn{4}{|c|}{ NS } \\
\hline & Bio & \multicolumn{4}{|c|}{1.23} & \multicolumn{4}{|c|}{1.06} \\
\hline & $\mathbf{N} \times$ Bio & \multicolumn{4}{|c|}{1.16} & \multicolumn{4}{|c|}{1.17} \\
\hline
\end{tabular}

Likewise, the co-inoculation gave increases reached with Azospirillum spp. (28.27 and $29.55 \%$ ) and with B. megaterium (32.38 and $3.11 \%$ ) and with B. polymyxa (34.52 and $33.16 \%)$ at 45 and 70 DAS, respectively. Results also, declared that the total bacterial counts increased with increasing $\mathrm{N}$-fertilizer rates, particularly in presence of the high rate, compared to the half rate. These data are in harmony with those obtained by El-Howeity (2004), 


\section{Plant Growth Criteria}

Data presented in Table ( 5 a \& b)shows the effect of the mixed inoculation with PGPR and nitrogen fertilization at two tested periods of faba bean plant growth on plant height, shoot and root dry weights. Significant variations in plant height shoot and root dry weights due to the application of nitrogen fertilizer were recorded during both seasons of the study, at 40 and 75 days after sowing every season, compared to the control .But insignificant differences were observed between the 20 and $40 \mathrm{~kg} / \mathrm{fed}$. of nitrogen fertilizer added on most studied traits.

Application of the biofertilizers resulted in the tallest plants and surpassed the control at 40th DAS by $(14.15,17.19,14.15$ and $17.92 \%)$ for $R$. leguminosarum , $R$. leguminosarum plus $A$. brasilense, $R$. leguminosarum plus $B$. megaterium and $R$. leguminosarum plus $B$. polymyxa, respectively. The same increases at $70^{\text {th }}$ DAS were (11.84, 15.56, 13.38 \& $17.48 \%$ ) with the above mentioned inocula . Likewise, addition of $R$. leguminosarum and co- inoculations resulted in significant increases in shoot dry weights, at $40^{\text {th }}$ DAS by $(13.22,14.02,11.37$ and $26.45 \%)$ and by $(8.89,19.46,12.78$ and $22.83 \%)$ at $75^{\text {th }}$ DAS with the same inoculants, $R$. leguminosarum , $R$. leguminosarum plus $A$. brasilense, $R$. leguminosarum plus $B$. megaterium and $R$.

leguminosarum plus $B$. polymyxa, respectively. Also, all of the experimental treatments led to increases in root dry matter. Increases of the root dry weight above the control were $(65.24,77.43,69.51$ and $90.24 \%)$ at $45^{\text {th }}$ DAS and $(19.72,71.46,53.36$ and $81.67 \%)$ at $70^{\text {th }}$ DAS with $R$. leguminosarum, $R$. leguminosarum plus $A$. brasilense, $R$. leguminosarum plus $B$. megaterium and $R$ leguminosarum plus $B$. polymyxa, respectively. Interaction between nitrogen fertilization and bioinoculations was found to be insignificant for most traits in both seasons, except at 75 days in the second one. Top response of faba bean plants to inoculation was recorded for the plants supplemented with the highest rate of nitrogen fertilizer together with the co inoculation. This enhancement of plant growth could be due to a possible $\mathrm{N}_{2}$-fixation and production of plant growth promoting substances by PGPR.

Crop Growth Rate (CGR):

It was obvious that considerable increases were occurred in plant crop growth rate based on each of plant height, shoot dry weight and root dry weight with increasing the nitrogen level up to $40 \mathrm{~kg} \mathrm{~N} / \mathrm{fed}$. (figs. 2, 3, 4, 5 and 6). The same effect was found using the biofertilizer treatments specially R.leguminosarum + B. polymyxa which was the most effective inoculum. These results are in harmony with those obtained by Mekhemar (2001), Dobbelaere et al.(2003) and El-Howeity (2008). Likewise, Rodelas et al. (1999) found that mixed inoculation of Vicia faba with four different $\mathrm{N}_{2}$-fixers namely, Rhizobium / Azospirillum and R. / Azotobacter increased dry weight of plants as compared with inoculation with Rhizobium alone. Such increase might be attributed to changes in total $\mathrm{N}$ content, concentration and / or distribution of mineral macro- and micronutrients ( $\mathrm{K}, \mathrm{P}, \mathrm{Ca}, \mathrm{Mg}, \mathrm{Fe}, \mathrm{B}, \mathrm{Mn}$, $\mathrm{Zn}$, and $\mathrm{Cu}$ ). 
J. Agric. Sci. Mansoura Univ., 34 (6), June, 2009

5 
El-Howeity, M. A. et al.

5 
J. Agric. Sci. Mansoura Univ., 34 (6), June, 2009

6 
Faba Bean Yield and Some of Its Attributes:

The response of faba bean yield and its attributes to nitrogen fertilization and inoculation with $R$. leguminosarum individually and coinoculation with Azospirillum spp. or Bacillus spp. is listed in Table (6). Results showed that faba bean yield and its attributes were significantly affected by nitrogen fertilization. Increasing the nitrogen rates caused significant increases in numbers of branches and pods / plant, number of seeds /pod, seed index and seed yield per plant and per feddan. In the other hand, slight but insignificant increases were detected for number of branches, in both seasons due to doubling the nitrogen levels (from 20 to $40 \mathrm{~kg} \mathrm{~N} / \mathrm{fed}$ ). In the second season, numbers of pods, and seeds/pod and seed yield /plant exerted increases. Seed yield / fed. of faba beans fertilized with mineral nitrogen exceeded significantly the control, i.e. by 52.5 and $27.8 \%$ in the first season and 53.2 and $15 \%$ in the second season, by 20 and $40 \mathrm{~kg} \mathrm{~N} / \mathrm{fed}$., respectively. In this concern, Mahmoud et al. (2006) reveled that $40 \mathrm{~kg}$ nitrogen/fed as soil treatment has significantly increased plant height, leaf area, total dry weight, number of pods, number of seeds per pod, seed yield. However, seed protein and carbohydrate proper accumulation required higher doses. Insanullah et al. (2008) stated that seed yield and shoot dry weight indicated significant quadratic relation with the increasing $\mathrm{N}$ rates between 0 and $200 \mathrm{~kg} \mathrm{ha}-1$.

The co inoculation especially with $R$. leguminosarum plus $B$. polymyxa attained the highest values of numbers of branches, and pods /plant, number of seeds and yield /plant and yield /fed., compared to the control and $R$. leguminosarum alone. The promotive effect of rhizobacteria as co inoculation with rhizobia on crop yield and its attributes has been demonstrated by many investigators ( Rodleas et al.,1999, Abdel-Wahab and Said, 2004 and El-Howeity, 2004 \& 2008).R.leguminosarum plus B. polymyxa as co-inoculation displayed significant increases in all yield characters compared to the control or $R$. leguminosarum alone or with other bacterial inoculants in both seasons. Average increases in yield/fed. reached $(67.45$ and $63.62 \%)$ for both seasons, respectively. It is worthy to note that the same treatment had higher number and dry weight of nodules, nitrogenase activity and total count of bacteria in rhizosphere soil. Followed by R.leguminosarum plus B.megaterium (41.65 and $50.62 \%)$ without significant differences with $(R+B$. polymyxa), then $R$. leguminosarum plus $A$. brasilense (33.95 and $45.33 \%$ ), and finally $R$. leguminosarum alone (29.96 and $36.85 \%$ ) above the control for both seasons, respectively. Introduction of the chemical nitrogen fertilizer enhanced plant elongation and branching, which led to highest dry weights of shoots and roots of faba bean plants (Table 5 a,b),and higher number of pods and weights of pod and seeds (Table 6).No significant differences between both of the nitrogen doses (20 and $40 \mathrm{kgN} / \mathrm{fed}$.). Regarding the interaction between the bio-agents and chemical nitrogen fertilizer on yield and its attributes,Table (6) showed that yield components displayed significant variations between the applied treatments and the response of faba bean to the biofertilizers and the chemical nitrogen fertilizer. Babiker et al.(1995) Nitrogen fertilization alone or $\mathrm{N}$ fixation significantly improved both yield and protein content, because 
plants make use of $\mathrm{N}$ added or fixed for growth and development and for seed production and composition.
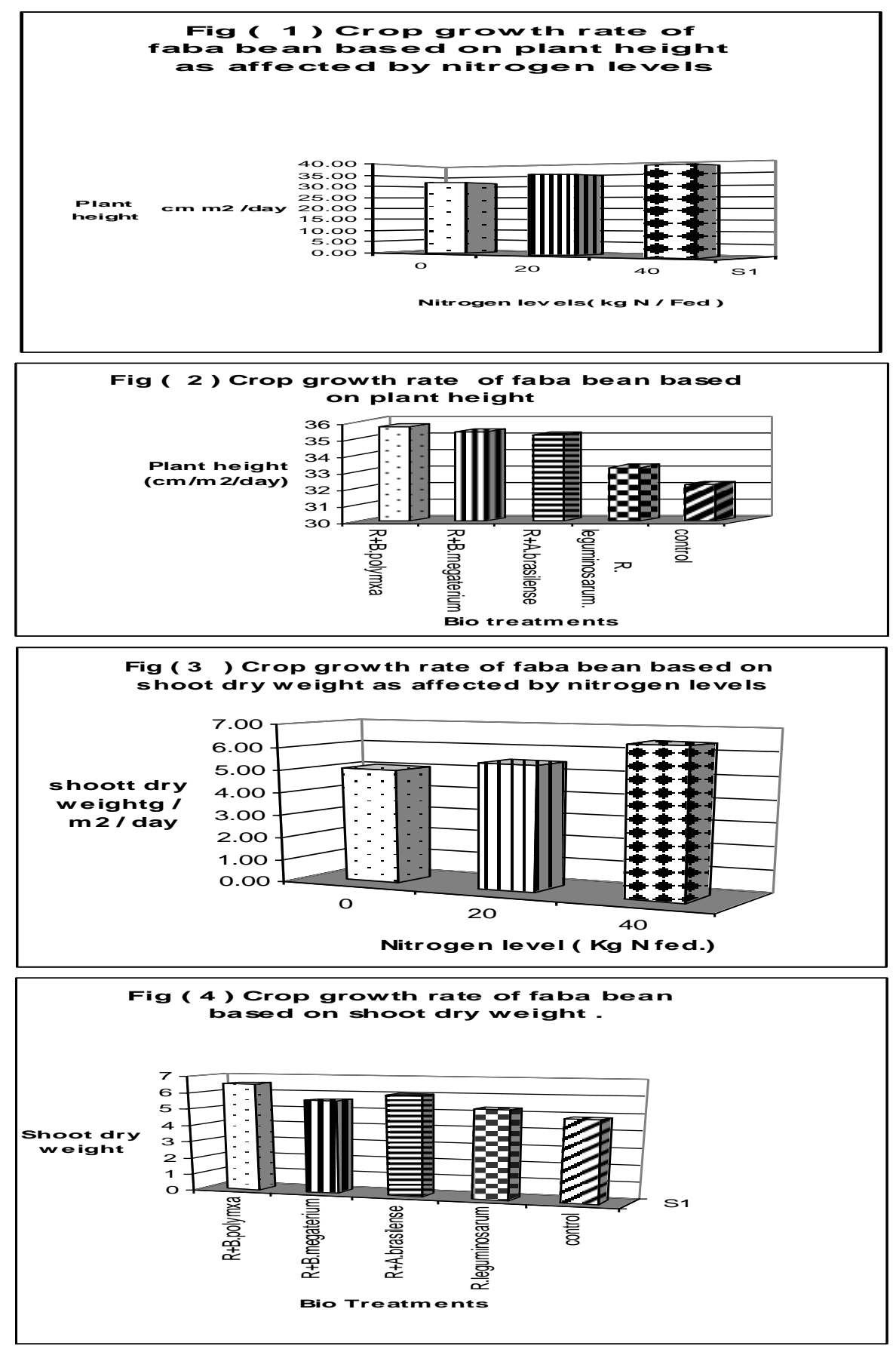
El-Howeity, M. A. et al.
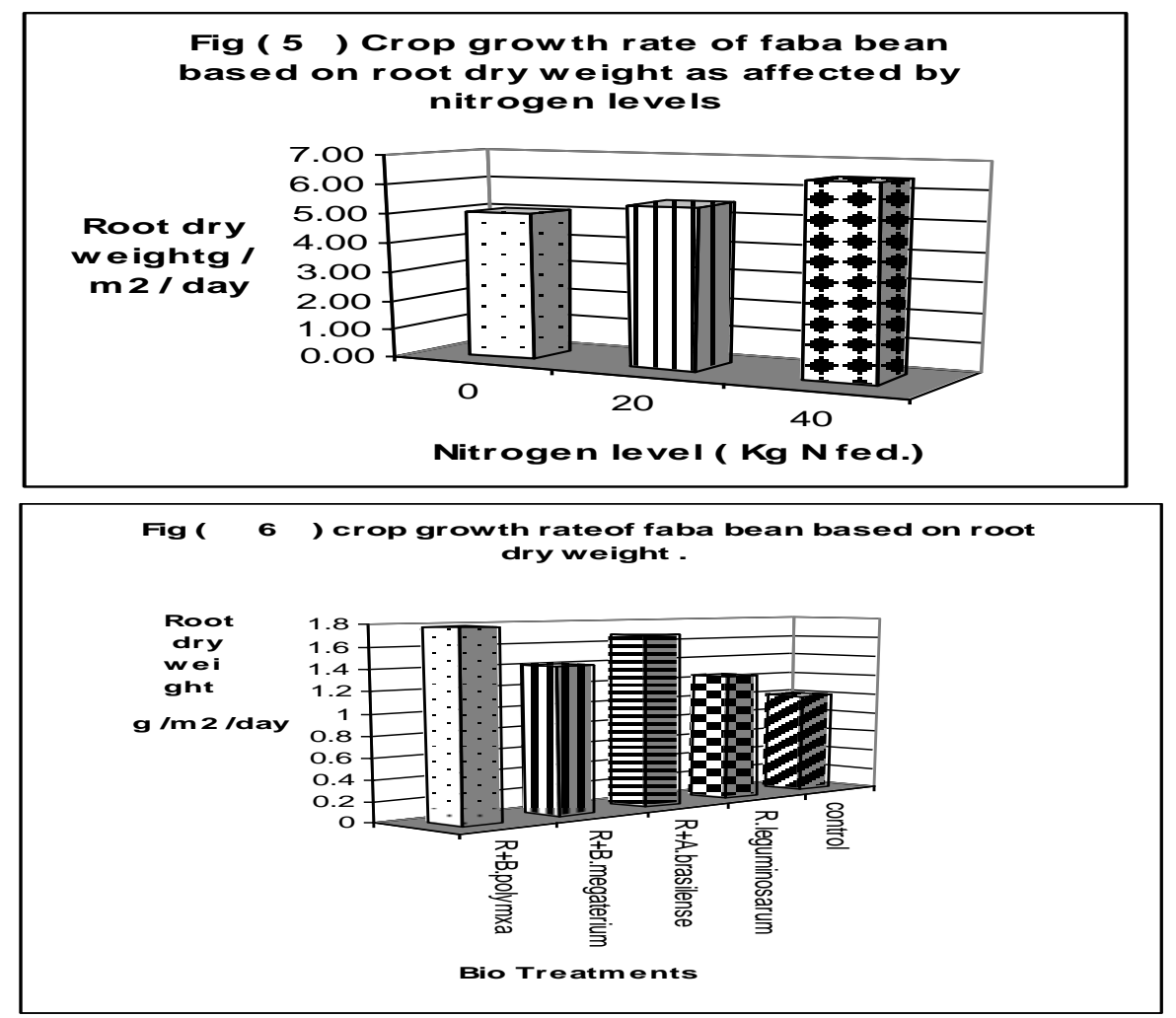

The Effect of biofertilizers and nitrogen levels on $\mathrm{N}$ and $\mathrm{P}$ contents of faba bean seeds:

Although there were gradual increases in $\mathrm{N} \%$ of faba bean seeds by increasing nitrogen fertilization levels, no significant association could be obtained due to nitrogen fertilization affecting seed nitrogen or phosphorous percentage in both season. On the other hand significant differences were observed by application of bio fertilization treatments on both nitrogen and phosphorous contents in faba bean seeds. R.+B.polymyxa exhibited the maximum values of nitrogen percentage, while $R .+B$ megaterium recorded the highest values of phosphorous percentage of faba bean seeds in both seasons. These results may sport high yielding ability especially in the second season.

It could be concluded that the addition of $R$. leguminosarum plus $B$. polymyxa as co- inoculation enhanced the nodulation status, growth characters and yield of faba bean plants particularly under the newly reclaimed land conditions. Application of $20 \mathrm{~kg}$ chemical nitrogen fertilizer /fed. is also recommended for better crop yield quantity and quality. 
J. Agric. Sci. Mansoura Univ., 34 (6), June, 2009

Table (7): The effect of biofertilizers and nitrogen levels on NP contents of faba bean and seeds

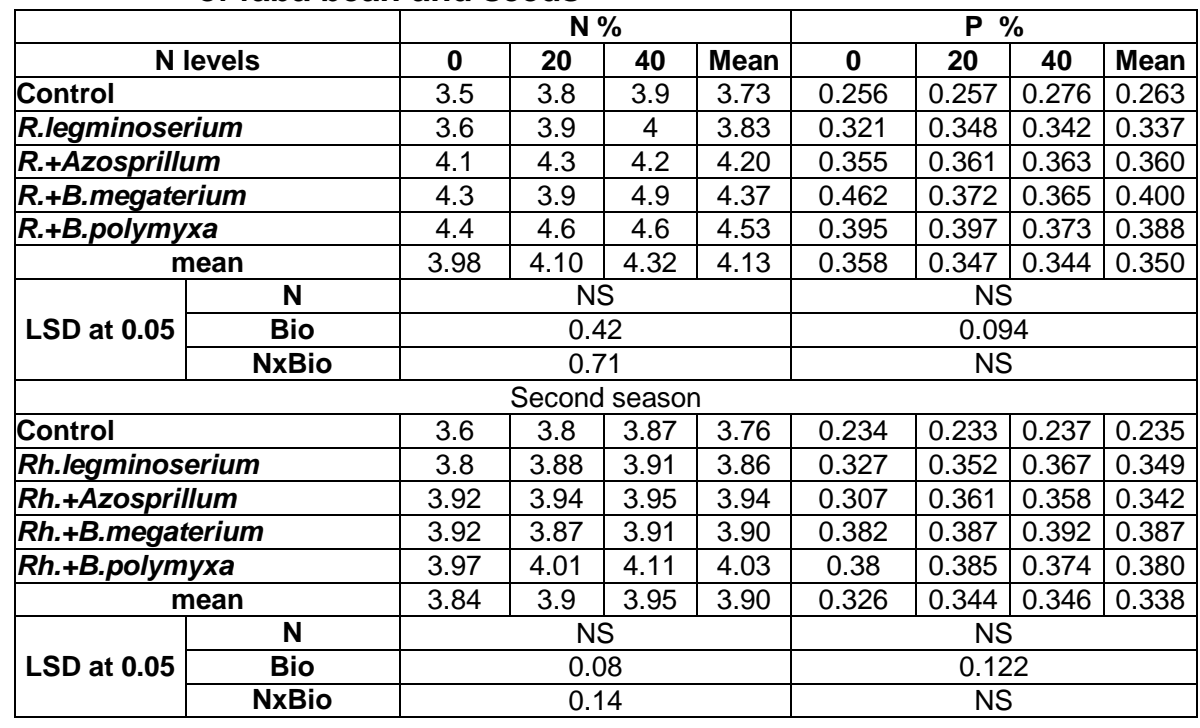

\section{REFERENCES}

Abdel-Wahab,A.F. and M.S.Said (2004). Response of faba bean to bio and organic fertilization under calcareous soil conditions. Egypt. J. Appl. Sci., 19(1): 305-320.

Aseri, G. K. and J. C. Tarafdar (2006). Fluoresein diacetate :a potential biological indicator for arid soils. Arid Land Res. Manage., 20: 87-99.

Babiker, E. E., E. A. E. El Sheikh, A.I. Osman and A. H. El -Tinay.(1995). Effect of nitrogen fixation, nitrogen fertilization and viral infection on yield, tannin and protein contents and in vitro protein digestibility of faba bean. Plant Foodsfor Human Nutrition 47: 257-263,1995.@ 1995 Kluwer Academic Publishers. Printed in the Netherlands.

Burdman,S., J.Kigel and Y.Okon( 1998). Effects of Azospirillum brasilense on nodulation and growth of common bean (Phaseolus vulgaris). Soil Biol. Biochem., 29 (5/6): 923-929.

Burns, R.G.(1982). Enzyme activity in soil : location and a possible role in microbial ecology . Soil Biol. Biochem., 14:423- 427.

Cassan,F.,D.Perring, V.Sgroy, O.Masciarelli, C.Penna and V.Luna(2008). Azospirillum brasilense AZ39 and Bradyrhizobium japonicum E109, inoculated singly or in compination, promote seed germination and early seedling growth in corn (Zea mays L.)and soybean(Glycine max L.). Eur. J. Soil Biol.,10:1-8.

Difco Manual (1985). Dehydrated Culture Nedia and Reagents for Microbiology $.10^{\text {th }}$ Ed.Difco Laboratories, Detroit, Michigan 4823, USA: 487-623. 
El-Howeity, M. A. et al.

Dobbelaere, S., J. Vanderleyden and Y.Okon(2003). Plant growth promotinon of diazotrophs in the rhizosphere. Critical Reviews in plant Sci., 22(2): 107-149.

El-Howeity M.A.(2004). Colonization patterns of diazotrophs associated with legume and non-legume crops. Ph.D., Dept. Soil Sci., Fac. Agric., Minufiya Univ., Egypt.

El- Howeity, M. A. (2008). Diazotrophy and growth of beans (Phaseolus vulgaris) genotypes inoculated with rhizobia and Lactic acid bacteria. Minufiya J. Agric. Res., 33(5):1283-1269.

Glick, B. R. (1995). The enhancement of plant growth by free -living bacteria. Can. J. Microbiol., 41:109-117.

Glick, B. R., C. L. Patten, G. Holguin and D. M. Penrose (1999). Biochemical and genetic mechanisms used by plant growth -promoting bacteria . Imperial College Press, London, UK.

Gomez ,K. A. and A. A. Gomez (1984). Statistical Procedure for Agriculture Research A Wiley Interscience Publication, John Wiley and Sons Inc. ,New York, USA.

Hardy,R.F., R.C.Burns and R.D.Holsten(1973). Applications of the acetylene -ethylene assay for measurement of nitrogen fixation. Soil Biol. Biochem.,5:47-81.

Hegazi, N. A. and S. Niemela (1976). A note of the estimation of Azotobacter densities by membrane filter technique. J. Appl.Bacteriol., 41:311.

Insanullah Daur, Hasan Sepetoğlu, Khan Bahadar Marwat, Gul Hassan and ljaz Ahmad Khan(2008). Effect of different levels of nitrogen on dry matter and grain yield of faba bean (Vicia faba L.) Pak. J. Bot., 40(6): 2453-2459.

Kohler, J., F. Caravaca, L. Carrasco and A. Rolden( 2007). Interaction between a plant growth -promoting rhizobacteria on AM fungus and phosphate -solubilizing fungus in the rhizosphere of Lactuca sativa. Appl. Soil Ecol., I35 : 480-487.

Mekhemar, G. A. A. (2001). Response of faba bean to co-inoculation with Rhizobium legminosarum and Bacillus megaterium under different levels of phosphatefertilization in newly reclaimed lands. J. Agric. Sci.Mansoura Univ., 6(12):8129-

Mahmoud, M. Shaaban, Abdalla , Fouad El-Sayed, Abou El-Nour, ElZanaty, Abdel Mottaleb Aly, El-Saady and Abdel Kareem Mohamed ( 2006 ). Boron/Nitrogen Interaction Effect on Growth and Yield of Faba Bean Plants Grown under Sandy Soil Conditions. International Journal of Agricultural Research. 1 (4): 322-330.

Okon,Y. and Labandera Gonzalez( 1994). Agronomic applications of Azospirillum: an evaluation of 20 years worldwide field inoculation experiments. Soil Biol. Biochem., 26: 1591-1601.

Okon,Y. and R. Itzigsohn (1995). The development of Azospirillum as a commercial inoculant for improving crop yields. Biotechnol. Advances. $13: 415-424$.

Okon Y. and J. Vanderleyden (1997). Root- associated Azospirillum species can stimulate plants, ASM News 63: 366-370. 
Page, A. L. , R. H. Miller and D. R. Keeney (1982). Methods of Soil Analysis. Part 2, $2^{\text {nd }}$ ed. Amer. Soc. Agron., Inc., Mad.,Wisc., USA.

Plazinski, J. and B. G. Rolfe ( 1985) .Azospirillum- Rhizobium interaction leading to a plant growth stimulation without nodule formation. Con. J. Microbiol., 31: 1026-1030

Richardson, A.E. (2001). Prospects for using soil microorganisms to improve the acquisition of phosphorus by plants. Aust.J. Plant Physiol.,28:897906.

Rodelas, B., G. Lopez, V. Salmeron, C. Pozo, M. V. Toledo (1996). Enhancement of nodulation, $\mathrm{N}_{2}$-fixation and growth of faba bean (Vicia faba L.)by combined inoculation with Rhizobium leguminosarum and Azospirillum brasilense. Symbiosis. 21:175-186.

Rodelas, B., J. Gonzalz-Lopez, C. Pozo,V. Salmeron and M.V. MartinezToledo (1999). Response of faba bean (Vicia faba) to combined inoculation with Azotobacter and Rhizobium leguminosarum bv.viceae. Appl. Soil Ecol., 12:51-59.

Tabatabai, M. A. (1982). Soil Enzymes. In: A. L. Page et al. (ed.) Methods of Soil Analysis, Part 2. Amer. Soc. Agron., Inc., Mad., Wisc., USA.

Tarafdar, J. G. and A. Gharu(2006). Mobilization of organic and poorly soluble phosphorus by chaetomium globosum. Appl. Soil Ecol., 32 :273- 283.

Thalmann, A. (1967). Uber die microbiello aktiviatat merkmalen einiger acherboden unter besonderer beruksi chtigung der dehydrognase activiatat (T.T.C. Reduktion).Biss, Gieben. Ph.D.Thesis, W. Germany.

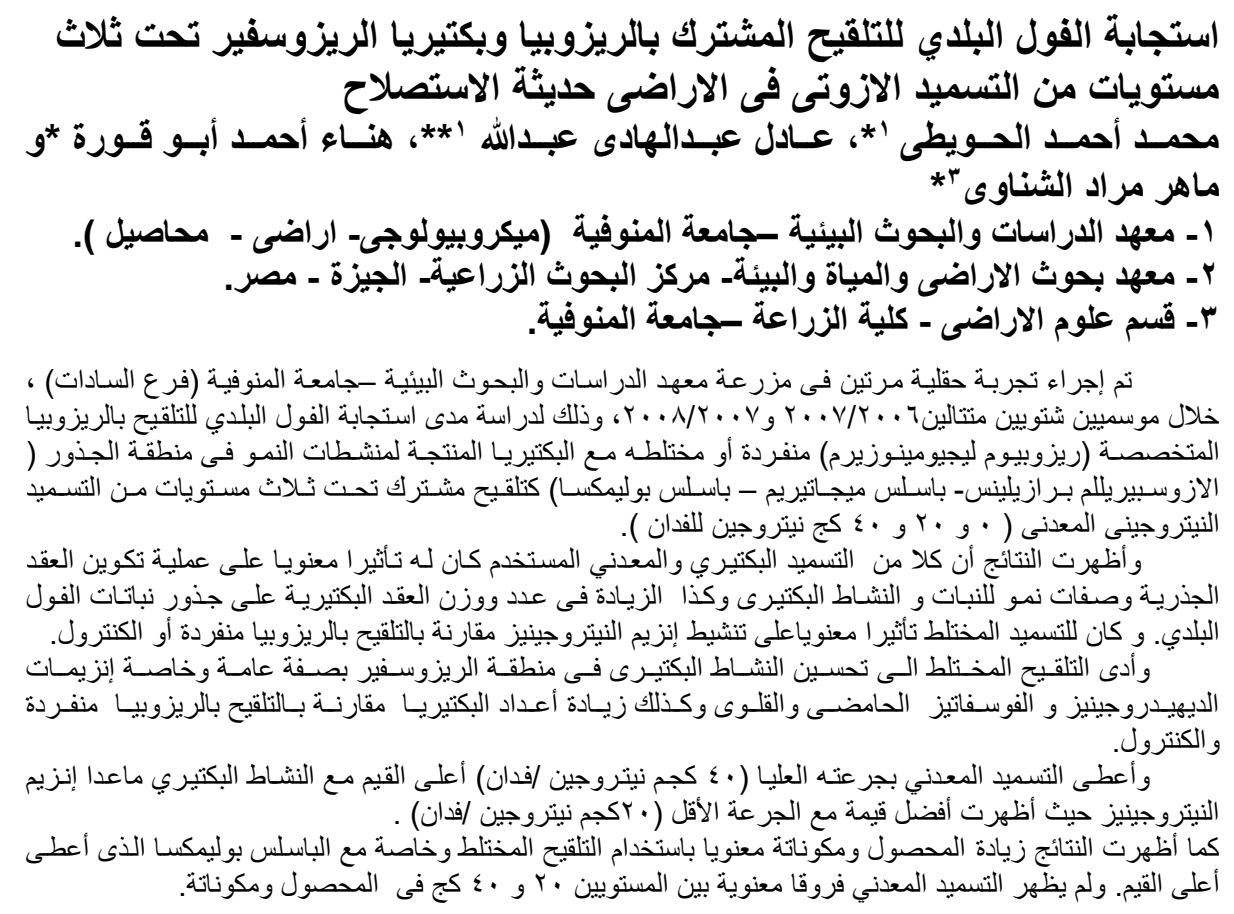


Table (2a): Effect of rhizobacteria and nitrogen fertilization on root nodulation and nitrogenase activity of faba bean plants at 45 and 70 days after sowing (first season)

\begin{tabular}{|c|c|c|c|c|c|c|c|c|c|c|c|c|c|}
\hline \multirow{2}{*}{\multicolumn{2}{|c|}{ Treatment }} & \multicolumn{4}{|c|}{ Number of nodules/ plant } & \multicolumn{4}{|c|}{ Dry weight of nodules ( $\mathrm{mg} / \mathrm{plant}$} & \multicolumn{4}{|c|}{ Nitrogenase activity $^{*}$} \\
\hline & & $\begin{array}{c}0 \\
\mathrm{kgN} / \mathrm{fed} .\end{array}$ & $\begin{array}{c}20 \\
\mathbf{k g N} / \\
\text { fed. }\end{array}$ & $\begin{array}{c}40 \\
\mathrm{kgN} / \\
\text { fed. }\end{array}$ & mean & $\begin{array}{c}0 \mathrm{kgN} / \\
\text { fed. }\end{array}$ & \begin{tabular}{|c|}
20 \\
$\mathrm{kgN} /$ \\
$\mathrm{fed}$.
\end{tabular} & $\begin{array}{c}40 \\
\mathrm{kgN} / \\
\text { fed. }\end{array}$ & mean & $\begin{array}{c}0 \mathrm{kgN} / \\
\text { fed. }\end{array}$ & $\begin{array}{c}20 \\
\mathrm{kgN} / \\
\text { fed. }\end{array}$ & $\begin{array}{c}40 \\
\text { kgN/ } \\
\text { fed. }\end{array}$ & mean \\
\hline \multicolumn{14}{|c|}{45 days after sowing } \\
\hline \multicolumn{2}{|c|}{ Control } & 11 & 13 & 14 & 12.67 & 200.00 & 254.00 & 254.00 & 236.00 & $5 . .54$ & 7.29 & 6.06 & 6.675 \\
\hline \multicolumn{2}{|c|}{ R.legminoserium } & 20 & 23 & 26 & 23.00 & 291.00 & 306.00 & 305.00 & 300.67 & 11.61 & 14.81 & 11.73 & 13.27 \\
\hline \multicolumn{2}{|c|}{ R.I.+Azosprillum } & 22 & 27 & 29 & 26.00 & 291.00 & 280.00 & 342.00 & 304.33 & 36.95 & 42.08 & 30.93 & 36.505 \\
\hline \multirow{2}{*}{\multicolumn{2}{|c|}{$\begin{array}{l}\text { R.I.+B.megateriu } \\
\text { R.I.+B.polymyxa }\end{array}$}} & 23 & 29 & 30 & 27.33 & 298.00 & 319.00 & 335.00 & 317.33 & 25.05 & 30.29 & 24.4 & 27.345 \\
\hline & & 23 & 27 & 29 & 26.33 & 300.00 & 312.00 & 324.00 & 312.00 & 28.49 & 30.86 & 33.23 & 32.045 \\
\hline \multicolumn{2}{|c|}{ Bio mean } & 19.80 & 23.80 & 25.60 & 23.07 & 276.00 & 294.20 & 312.00 & 294.07 & 25.53 & 29.51 & 25.07 & 27.29 \\
\hline \multirow{3}{*}{$\begin{array}{l}\text { LSD, } \\
\text { at } 0.05\end{array}$} & $\mathbf{N}$ & \multicolumn{4}{|c|}{2.3} & \multicolumn{4}{|c|}{18.41} & \multicolumn{4}{|c|}{3.51} \\
\hline & Bio & \multirow{2}{*}{\multicolumn{4}{|c|}{$\begin{array}{l}3.16 \\
4.36\end{array}$}} & \multirow{2}{*}{\multicolumn{4}{|c|}{$\frac{7.62}{2156}$}} & \multicolumn{4}{|c|}{5.23} \\
\hline & Nx Bio & & & & & & & & 21.56 & \multicolumn{4}{|c|}{5.11} \\
\hline
\end{tabular}

\begin{tabular}{|c|c|c|c|c|c|c|c|c|c|c|c|c|c|}
\hline \multicolumn{14}{|c|}{ 70days after sowing } \\
\hline \multicolumn{2}{|c|}{ Control } & 16 & 17 & 19 & 17.33 & 332 & 348 & 359 & 346.33 & 12.25 & 15.67 & 14.22 & 14.05 \\
\hline \multicolumn{2}{|c|}{ Rh.legminoserium } & 26 & 32 & 33 & 30.33 & 393 & 422 & 428 & 414.44 & 51.08 & 61.47 & 54.12 & 55.56 \\
\hline R.I. & rillum & 31 & 36 & 40.3 & 35.77 & 411 & 438 & 455 & 434.67 & 86.88 & 103.58 & 93.31 & 94.59 \\
\hline \multicolumn{2}{|c|}{ R.I.+B.megaterium } & 35 & 39 & 40 & 38.00 & 386 & 440 & 461 & 429.00 & 65.17 & 76.05 & 72.73 & 71.32 \\
\hline \multicolumn{2}{|c|}{ R.I.+B.polymyxa } & 33 & 38 & 39 & 36.67 & 418 & 434 & 443 & 431.67 & 71.37 & 79.05 & 73.45 & 74.62 \\
\hline & & 28.20 & 32.40 & 34.26 & 31.62 & 388.00 & 416.40 & 429.27 & 411.22 & 57.35 & 67.16 & 61.57 & 62.03 \\
\hline \multirow{3}{*}{$\begin{array}{l}\text { LSD, } \\
\text { at } 0.05\end{array}$} & $\mathbf{N}$ & \multicolumn{4}{|c|}{1.75} & \multicolumn{4}{|c|}{17.65} & \multicolumn{4}{|c|}{3.41} \\
\hline & Bio & \multirow{2}{*}{\multicolumn{4}{|c|}{$\begin{array}{l}3.16 \\
4.23\end{array}$}} & \multirow{2}{*}{\multicolumn{4}{|c|}{$\begin{array}{c}9.43 \\
12.33\end{array}$}} & \multicolumn{4}{|c|}{8.16} \\
\hline & Nx Bio & & & & & & & & & \multicolumn{4}{|c|}{12.78} \\
\hline
\end{tabular}

${ }^{*} \mu \mathrm{mol} \mathrm{C}_{2} \mathrm{H}_{4} / \mathrm{hr} / \mathrm{g}$ dry weight of plant. 
Table (2 b): Effect of rhizobacteria and nitrogen fertilization on root nodulation and nitrogenase activity of faba bean plants at $\mathbf{4 5}$ and $\mathbf{7 0}$ days after sowing (second season)

\begin{tabular}{|c|c|c|c|c|c|c|c|c|c|c|c|c|c|}
\hline \multirow{2}{*}{\multicolumn{2}{|c|}{ Treatment }} & \multicolumn{4}{|c|}{ Number of nodules/plant } & \multicolumn{4}{|c|}{ Dry weight of nodules ( $\mathrm{mg} /$ plant) } & \multicolumn{4}{|c|}{ Nitrogenase activity * } \\
\hline & & $\begin{array}{c}0 \\
\mathrm{kgN} / \mathrm{fed}\end{array}$ & $\begin{array}{c}20 \\
\text { kgN/ } \\
\text { fed. }\end{array}$ & $\begin{array}{c}40 \\
\text { kgN/ } \\
\text { fed. }\end{array}$ & mean & $\begin{array}{c}0 \mathbf{~ k g N} / \\
\text { fed. }\end{array}$ & $\begin{array}{c}20 \\
\mathrm{kgN} / \\
\text { fed. }\end{array}$ & \begin{tabular}{|c|}
40 \\
$\mathrm{kgN} / \mathrm{fed}$
\end{tabular} & mean & $\begin{array}{l}0 \mathrm{kgN} / \\
\text { fed. }\end{array}$ & $\begin{array}{c}20 \\
\mathrm{kgN} / \mathrm{fed} .\end{array}$ & $\begin{array}{c}40 \\
\mathrm{kgN} / \mathrm{fed}\end{array}$ & mean \\
\hline \multicolumn{14}{|c|}{45 days after sowing } \\
\hline \multirow{6}{*}{\multicolumn{2}{|c|}{$\begin{array}{c}\text { Control } \\
\text { R.legminoserium } \\
\text { R.I.+Azosprillum } \\
\text { R.I.+B.megaterium } \\
\text { R.I.+B.polymyxa }\end{array}$}} & 12 & 14 & 15 & 13.67 & 206 & 253 & 260 & 239.67 & 5.96 & 8.12 & 7.01 & 7.03 \\
\hline & & 19 & 22 & 28 & 23.00 & 285 & 305 & 317 & 302.33 & 20.94 & 23.73 & 19.02 & 21.23 \\
\hline & & 20 & 26 & 32 & 26.00 & 290 & 317 & 328 & 311.67 & 34.58 & 41.09 & 33.31 & 36.33 \\
\hline & & 25 & 32 & 31 & 29.33 & 297 & 322 & 331 & 316.67 & 25.68 & 31.07 & 28.02 & 28.26 \\
\hline & & 22 & 26 & 32 & 26.67 & 296 & 320 & 329 & 315.00 & 35.89 & 45.32 & 41.93 & 41.05 \\
\hline & & 19.60 & 24.00 & 27.60 & 23.73 & 274.80 & 303.40 & 313.00 & 297.07 & 24.61 & 29.87 & 25.86 & 26.78 \\
\hline \multirow{3}{*}{$\begin{array}{l}\text { LSD, } \\
\text { at } 0.05\end{array}$} & $\mathbf{N}$ & \multicolumn{4}{|c|}{3.14} & \multicolumn{4}{|c|}{9.06} & \multicolumn{4}{|c|}{3.26} \\
\hline & Bio & \multirow{2}{*}{\multicolumn{4}{|c|}{$\frac{4.32}{5.18}$}} & \multirow{2}{*}{\multicolumn{4}{|c|}{$\begin{array}{c}8.09 \\
1153\end{array}$}} & \multicolumn{4}{|c|}{5.84} \\
\hline & $\mathbf{N} \times \mathbf{B i}$ & & & & & & & & & \multicolumn{4}{|c|}{13.07} \\
\hline \multicolumn{14}{|c|}{ 70days after sowing } \\
\hline \multicolumn{2}{|c|}{ Control } & 16 & 18 & 18.67 & 17.56 & 341 & 357 & $\begin{array}{l}390 \\
\end{array}$ & 362.67 & 12.96 & 15.51 & 15.49 & 14.65 \\
\hline \multirow{2}{*}{\multicolumn{2}{|c|}{$\begin{array}{l}\text { R.legminoserium } \\
\text { R.I.+Azosprillum }\end{array}$}} & 29 & 36 & 36 & 33.67 & 405 & 440 & 434 & 426.33 & 58.3 & 68.95 & 65.38 & 64.21 \\
\hline & & 34 & 40 & 40 & 38.00 & 411 & 447 & 471 & 443.00 & 87.8 & 108.65 & 88.18 & 94.88 \\
\hline \multicolumn{2}{|c|}{ R.I.+B.megaterium } & 36 & 42 & 41 & 39.67 & 414 & 456 & 468 & 446.00 & 69 & 87.34 & 78.17 & 78.17 \\
\hline \multirow{2}{*}{\multicolumn{2}{|c|}{ R.I.+B.polymyxa }} & 35 & 41 & 40 & 38.67 & 402 & 440 & 451 & 431.00 & 85.03 & 120 & 107.46 & 104.16 \\
\hline & & 30.00 & 35.40 & 35.13 & 33.51 & 394.60 & 428.00 & 442.80 & 421.80 & 62.62 & 80.09 & 70.94 & 71.21 \\
\hline \multirow{3}{*}{$\begin{array}{l}\text { LSD, } \\
\text { at } 0.05\end{array}$} & $\mathbf{N}$ & \multirow{3}{*}{\multicolumn{4}{|c|}{$\begin{array}{l}4.16 \\
7.14 \\
9.79\end{array}$}} & \multicolumn{4}{|c|}{23.87} & \multicolumn{4}{|c|}{7.61} \\
\hline & Bio & & & & & \multirow{2}{*}{\multicolumn{4}{|c|}{$\begin{array}{l}15.88 \\
159 ?\end{array}$}} & \multicolumn{4}{|c|}{11.93} \\
\hline & $\mathbf{N} \times \mathbf{B i}$ & & & & & & & & & \multicolumn{4}{|c|}{19.55} \\
\hline
\end{tabular}

${ }^{*} \mu \mathrm{mol} \mathrm{C} \mathrm{H}_{2} / \mathrm{hr} / \mathrm{g}$ dry weight of plant. 
Table( 3 a): Effect of rhizobacteria and nitrogen fertilization on enzyme activities in rhizosphere of faba bean plants at $\mathbf{4 5}$ and $\mathbf{7 0}$ days after sowing (first season)

\begin{tabular}{|c|c|c|c|c|c|c|c|c|c|c|c|c|c|}
\hline \multirow{2}{*}{\multicolumn{2}{|c|}{ Treatments }} & \multicolumn{4}{|c|}{ DHA $\mu \mathrm{g}$ TPF/ g dry soil / day } & \multicolumn{4}{|c|}{ Acid Phosphatse ( $\mu \mathrm{gP} / \mathrm{gdry}$ soil) } & \multicolumn{4}{|c|}{ Alkalin Phosphatse ( $\mu \mathrm{gP} / \mathrm{gdry}$ soil) } \\
\hline & & $\begin{array}{c}0 \mathrm{~kg} \\
\mathrm{~N} / \mathrm{fed} .\end{array}$ & $20 \mathrm{kgN} / \mathrm{fed}$ & $40 \mathrm{kgN} / \mathrm{fed}$ & mean & $\begin{array}{c}0 \\
\mathrm{kgN} / \mathrm{fed}\end{array}$ & $20 \mathrm{kgN} / \mathrm{fed}$ & $40 \mathrm{kgN} / \mathrm{fed}$ & mean & $\begin{array}{c}0 \\
\mathrm{kgN} / \mathrm{fed} .\end{array}$ & $20 \mathrm{kgN} / \mathrm{fed}$. & $40 \mathrm{kgN} / \mathrm{fed}$. & mean \\
\hline \multicolumn{14}{|c|}{45 days after sowing } \\
\hline \multicolumn{2}{|c|}{ Control } & 4.75 & 5.53 & 6.86 & 5.71 & 19.45 & 30.88 & 37.59 & 29.31 & 10.98 & 25.64 & 39.3 & 25.31 \\
\hline \multicolumn{2}{|c|}{ R.legminoserium } & 6.41 & 12.95 & 14.87 & 11.41 & 29.28 & 49.9 & 75.28 & 51.49 & 41.25 & 51.2 & 41.03 & 44.49 \\
\hline \multicolumn{2}{|c|}{ R.I.+Azosprillum } & 7.73 & 13.6 & 16.26 & 12.53 & 42.97 & 83.91 & 120.91 & 82.60 & 37.97 & 76.03 & 108.84 & 73.41 \\
\hline \multirow{2}{*}{\multicolumn{2}{|c|}{$\begin{array}{c}\text { R.I.+B.megaterium } \\
\text { R.I.+B.polymyxa }\end{array}$}} & 7.11 & 13.45 & 16.63 & 12.40 & 51.08 & 101.9 & 151.56 & 101.51 & 43.56 & 78.2 & 146.48 & 89.41 \\
\hline & & 7.31 & 14.32 & 18.45 & 13.36 & 44.9 & 86.64 & 128.5 & 86.68 & 43.28 & 70.15 & 97.89 & 70.44 \\
\hline \multicolumn{2}{|c|}{ Mean } & 6.66 & 11.97 & 14.61 & 11.08 & 37.54 & 70.65 & 102.77 & 70.32 & 35.408 & 56.2975 & 86.708 & 59.47 \\
\hline \multirow{3}{*}{$\begin{array}{l}\text { LSD, } \\
\text { at } 0.05\end{array}$} & $\mathbf{N}$ & \multicolumn{4}{|c|}{3.20} & \multicolumn{4}{|c|}{10.72} & \multicolumn{4}{|c|}{9.56} \\
\hline & Bio & \multirow{2}{*}{\multicolumn{4}{|c|}{$\begin{array}{l}2.31 \\
5.43\end{array}$}} & & & & & & 8.4 & & \\
\hline & $\mathrm{N} \times$ Bio & & & & & \multicolumn{4}{|c|}{$\frac{12.17}{21.18}$} & \multicolumn{4}{|c|}{9.6} \\
\hline \multicolumn{14}{|c|}{70 days after sowing } \\
\hline \multicolumn{2}{|c|}{ Control } & 8.25 & 10.05 & 12.49 & 10.26 & 54.54 & 70.3 & 72.24 & 65.69 & 52.68 & 60.62 & 60.62 & 57.97 \\
\hline \multirow{2}{*}{\multicolumn{2}{|c|}{ R.legminoserium }} & 18.85 & 23.7 & 25.46 & 22.67 & 88.42 & 106.82 & 120.33 & 105.19 & 76.63 & 87.31 & 107.75 & 90.56 \\
\hline & & 19.82 & 26.52 & 27.4 & 24.58 & 120.25 & 148.05 & 165.48 & 144.59 & 104.6 & 142.77 & 146.62 & 131.33 \\
\hline \multicolumn{2}{|c|}{$\begin{array}{c}\text { R.I.+Azosprillum } \\
\text { R.I.+B.megaterium }\end{array}$} & 19.49 & 24.83 & 27 & 23.77 & 181.25 & 197.68 & 215.9 & 198.28 & 119.38 & 128.81 & 165.24 & 137.81 \\
\hline \multicolumn{2}{|c|}{ R.I.+B.polymyxa } & 20.92 & 26.17 & 27.97 & 25.02 & 124.3 & 150.18 & 171.11 & 148.53 & 112.81 & 127.46 & 136.32 & 125.53 \\
\hline \multicolumn{2}{|c|}{ Mean } & 17.47 & 22.25 & 24.06 & 21.26 & 113.75 & 134.61 & 149.01 & 132.46 & 93.22 & 109.394 & 123.31 & 108.64 \\
\hline \multirow{3}{*}{$\begin{array}{l}\text { LSD, } \\
\text { at } 0.05\end{array}$} & $\mathbf{N}$ & \multicolumn{4}{|c|}{3.62} & \multicolumn{4}{|c|}{12.91} & \multicolumn{4}{|c|}{11.27} \\
\hline & Bio & \multirow{2}{*}{\multicolumn{4}{|c|}{$\begin{array}{l}3.07 \\
8.21\end{array}$}} & \multirow{2}{*}{\multicolumn{4}{|c|}{$\begin{array}{l}17.05 \\
23.16\end{array}$}} & \multirow{2}{*}{\multicolumn{4}{|c|}{$\frac{16.43}{2217}$}} \\
\hline & N $\times$ Bio & & & & & & & & & & & & \\
\hline
\end{tabular}


Table (3 b): Effect of rhizobacteria and nitrogen fertilization on enzyme activities in rhizosphere of faba bean plants at 45 and 70 days after sowing (second season)

\begin{tabular}{|c|c|c|c|c|c|c|c|c|c|c|c|c|c|}
\hline \multirow{2}{*}{\multicolumn{2}{|c|}{ Treatments }} & \multicolumn{4}{|c|}{ DHA $\mu \mathrm{g}$ TPF/ g dry soil / day } & \multicolumn{4}{|c|}{ Acid Phosphatse $(\mu \mathrm{gP} / \mathrm{g}$ dry soil) } & \multicolumn{4}{|c|}{ Alkalin Phosphatse $(\mu \mathrm{gP} / \mathrm{g}$ dry soil) } \\
\hline & & $\begin{array}{c}0 \\
\mathrm{kgN} / \mathrm{fed}\end{array}$ & $20 \mathrm{kgN} / \mathrm{fed}$. & $40 \mathrm{kgN} / \mathrm{fed}$ & mean & $\begin{array}{c}0 \\
\mathrm{kgN} / \mathrm{fed}\end{array}$ & $20 \mathrm{kgN} / \mathrm{fed}$ & $40 \mathrm{kgN} / \mathrm{fed}$. & mean & $\begin{array}{c}0 \\
\mathrm{kgN} / \mathrm{fed}\end{array}$ & $20 \mathrm{kgN} / \mathrm{fed}$. & $40 \mathrm{kgN} / \mathrm{fed}$. & mean \\
\hline & & \multicolumn{12}{|c|}{ 45days after sowing } \\
\hline \multicolumn{2}{|c|}{ R.legminoserium } & 7.9 & 12.08 & 15.17 & 11.72 & 36.07 & 72.69 & 77.37 & 62.04 & 27.6 & 34.07 & 46.07 & 35.91 \\
\hline \multicolumn{2}{|c|}{ R.I.+Azosprillum } & 8.11 & 13.12 & 16.06 & 12.43 & 36.56 & 77.28 & 128.77 & 80.87 & 35.79 & 66.03 & 88.5 & 63.44 \\
\hline \multicolumn{2}{|c|}{ R.I.+B.megaterium } & 7.83 & 13.1 & 16.23 & 12.39 & 44.42 & 101.7 & 150.82 & 98.98 & 43.89 & 76.61 & 130.7 & 83.73 \\
\hline \multicolumn{2}{|c|}{$\begin{array}{c}\text { R.I.+B.polymyxa } \\
\text { Mean } \\
\end{array}$} & 8.25 & 14.06 & 16.94 & 13.08 & 40.19 & 83.7 & 118.48 & 80.79 & 37.19 & 64.86 & 88.15 & 63.40 \\
\hline \multirow{3}{*}{$\begin{array}{l}\text { LSD, at } \\
0.05\end{array}$} & $\mathbf{N}$ & \multicolumn{4}{|c|}{2.86} & \multicolumn{4}{|c|}{18.31} & \multicolumn{4}{|c|}{12.98} \\
\hline & Bio & \multirow{2}{*}{\multicolumn{4}{|c|}{$\frac{2.73}{4.18}$}} & \multirow{2}{*}{\multicolumn{4}{|c|}{$\frac{17.12}{1152}$}} & \multicolumn{4}{|c|}{5.43} \\
\hline & $\mathbf{N} \times$ Bio & & & & & \multirow{2}{*}{\multicolumn{4}{|c|}{$\frac{11.53}{\text { 70days after sowing }}$}} & \multicolumn{4}{|c|}{14.03} \\
\hline & & & & & & & & & & \\
\hline \multicolumn{2}{|c|}{ Control } & 9 & 11.31 & 12.91 & 11.07 & 54.54 & 68.26 & 75.47 & 66.09 & 43.51 & 53.89 & 65.05 & 54.15 \\
\hline \multirow{2}{*}{\multicolumn{2}{|c|}{$\begin{array}{l}\text { R.legminoserium } \\
\text { R.I.+Azosprillum }\end{array}$}} & $7 . .90$ & 8.98 & 13.1 & 11.04 & 88.42 & 138.57 & 150.12 & 125.70 & 56.9 & 102.27 & 117.54 & 92.24 \\
\hline & & 11.91 & 13.33 & 16.04 & 13.76 & 120.25 & 153.64 & 161.8 & 145.23 & 79.04 & 111.75 & 120.23 & 103.67 \\
\hline \multirow{2}{*}{$\begin{array}{l}\text { LSD, at } \\
0.05\end{array}$} & \begin{tabular}{|l|} 
Bio \\
\end{tabular} & \multirow{2}{*}{\multicolumn{4}{|c|}{$\begin{array}{l}1.26 \\
8.24\end{array}$}} & \multirow{2}{*}{\multicolumn{4}{|c|}{$\begin{array}{l}9.13 \\
29.57\end{array}$}} & \multirow{2}{*}{\multicolumn{4}{|c|}{$\frac{8.74}{12.05}$}} \\
\hline & N x Bio & & & & & & & & & & & & \\
\hline
\end{tabular}


Table ( 5 a): Effect of rhizobacteria and nitrogen fertilization on growth criteria of faba bean plants at 45 and 70 days after sowing (frist season)

\begin{tabular}{|c|c|c|c|c|c|c|c|c|c|c|c|c|c|c|}
\hline \multirow{2}{*}{\multicolumn{2}{|c|}{ Treatment }} & \multicolumn{4}{|c|}{ Plant height(Cm) } & \multicolumn{4}{|c|}{ Shoot d.wt.(g/ plant) } & \multicolumn{5}{|c|}{ Root d.wt.(g/plant) } \\
\hline & & $\begin{array}{l}0 \mathbf{~ k g N} / \\
\text { fed. }\end{array}$ & $\begin{array}{c}20 \mathrm{kgN} / \\
\text { fed. }\end{array}$ & $\begin{array}{l}40 \mathrm{kgN} / \\
\text { fed. }\end{array}$ & $\begin{array}{c}\mathrm{N} \\
\text { mean }\end{array}$ & $\begin{array}{l}0 \mathrm{kgN} / \\
\text { fed. }\end{array}$ & \begin{tabular}{|c|}
$\begin{array}{c}20 \mathrm{kgN} \\
\text { /fed. }\end{array}$ \\
\end{tabular} & \begin{tabular}{c|c}
$\mathbf{N}$ & $\begin{array}{c}40 \mathrm{kgN} / \\
\text { fed. }\end{array}$
\end{tabular} & $\begin{array}{c}\mathrm{N} \\
\text { mean }\end{array}$ & $\begin{array}{l}0 \mathbf{k g N} \\
\text { fed. }\end{array}$ & \multicolumn{2}{|c|}{$\begin{array}{l}20 \mathrm{kgN} / \\
\text { fed. }\end{array}$} & $\begin{array}{l}40 \mathrm{kgN} / \\
\text { fed. }\end{array}$ & $\begin{array}{c}\mathrm{N} \\
\text { mean }\end{array}$ \\
\hline \multicolumn{15}{|c|}{45 days after sowing } \\
\hline \multirow{2}{*}{\multicolumn{2}{|c|}{\begin{tabular}{|l|} 
Control \\
R leaminoserium
\end{tabular}}} & 27 & 30 & 33.6 & 30.20 & 3.12 & 3.88 & 4.22 & 3.74 & 1.17 & \multicolumn{2}{|c|}{1.46} & 2.02 & 1.55 \\
\hline & & 30.3 & 35.3 & 38 & 34.53 & 3.81 & 4.11 & 4.9 & 4.27 & 2.08 & \multicolumn{2}{|c|}{2.9} & 3 & 2.66 \\
\hline \multicolumn{2}{|c|}{ R.I.+Azosprillum } & 32.6 & 37 & 44.6 & 38.07 & \multirow{2}{*}{$\frac{3.43}{3.4}$} & 4.29 & 5.07 & 4.26 & 2.31 & \multicolumn{2}{|c|}{3.02} & 3.17 & 2.83 \\
\hline \multicolumn{2}{|c|}{ R. I.+B.megaterium } & 31.3 & 35.6 & 40 & 35.63 & & 4.3 & 4.76 & 4.18 & 2.13 & & $\frac{2.95}{31}$ & 3 & 2.69 \\
\hline \multicolumn{2}{|c|}{ R.I.+B.polymyxa } & 35 & 37 & 41.3 & 37.77 & 4 & 4.86 & 5.51 & 4.79 & 2.48 & 3 & & 3.23 & 2.94 \\
\hline \multicolumn{2}{|c|}{ Bio mean } & 31.24 & 34.98 & 39.5 & 35.24 & 3.55 & 4.30 & 4.89 & 4.25 & 2.03 & \multicolumn{2}{|c|}{2.69} & 2.89 & 2.53 \\
\hline & $\mathrm{N}$ & & 2. & & & & & .03 & & & & NS & & \\
\hline LSD. at 0.05 & Bio & & 3. & & & & & vS & & & & 0.43 & & \\
\hline & $\mathrm{N} \times \mathrm{Bi}$ & & $\mathrm{N}$ & & & & & Vs & & & & 0.65 & & \\
\hline & & & & & & days a & after sol & ing & & & & & & \\
\hline & & & Plant he & ight(Cm) & & & Shoot d. & t. (g/ plant & & & Root d.wt & g/pla & & \\
\hline & Control & & 99.6 & 120.3 & 131.6 & 117.17 & \begin{tabular}{|l|}
15.35 \\
\end{tabular} & \begin{tabular}{|l|l}
17.04 \\
\end{tabular} & 18.02 & 16.80 & 3.39 & 4.2 & 5.06 & 4.22 \\
\hline R.leg & minoser & ium & 112.3 & 122.3 & 138.3 & 124.30 & 16.66 & 18.56 & 20.53 & 18.58 & 5.39 & 6.2 & 6.44 & 6.01 \\
\hline R.I.t. & Azosprill & lum & 122 & 132 & 141.6 & 131.87 & 18.15 & 19.93 & 23.19 & 20.42 & 6.1 & 7. & 8.21 & 7.34 \\
\hline R.I. + L & 3.megate & erim & 121 & 132.3 & 140.6 & 131.30 & 16.8 & 18.91 & 22.02 & 19.24 & 5.59 & 6.3 & 7.43 & 6.47 \\
\hline R.I.t & B.polym & & 126.3 & 134.6 & 142 & 134.30 & 18.74 & 20.96 & 23.51 & 21.07 & 6.35 & 7. & 9.14 & 7.73 \\
\hline & & & 116.24 & 128.3 & 138.82 & 127.79 & 17.14 & 19.08 & 21.45 & 19.22 & 5.36 & 6.4 & 7.26 & 6.35 \\
\hline & & $\mathrm{N}$ & & 5. & & & & 1.64 & & & & & 1.06 & \\
\hline LSD. at 0.05 & & Bio & & 4. & & & & 1.34 & & & & & 1.14 & \\
\hline & & $\mathrm{N} \times$ Bio & & $\mathrm{N}$ & & & & NS & & & & & NS & \\
\hline
\end{tabular}


Table (5 b): Effect of rhizobacteria and nitrogen fertilization on growth criteria of faba bean plants at 45 and 70 days after sowing ( second season)

\begin{tabular}{|c|c|c|c|c|c|c|c|c|c|c|c|c|c|}
\hline \multirow{2}{*}{\multicolumn{2}{|c|}{ Treatment }} & \multicolumn{4}{|c|}{ Plant height $(\mathbf{C m})$} & \multicolumn{4}{|c|}{ Shoot dwt.(g/ plant) } & \multicolumn{4}{|c|}{ Root dwt. (g/plant) } \\
\hline & & $0 \mathrm{kgN} / \mathrm{fed}$. & $\begin{array}{l}20 \mathrm{kgN} / \\
\text { ed. }\end{array}$ & $\begin{array}{l}40 \mathrm{kgN} / \\
\mathrm{fed} .\end{array}$ & mean & $\begin{array}{c}0 \\
\mathrm{kgN} / \mathrm{fed}\end{array}$ & $\begin{array}{l}20 \mathrm{kgN} / \mathrm{f} \\
\mathrm{ed} .\end{array}$ & $\begin{array}{l}40 \mathrm{kgN} / \\
\text { fed. }\end{array}$ & mean & $\begin{array}{c}0 \\
\mathrm{kgN} / \mathrm{fed}\end{array}$ & $20 \mathrm{kgN} / \mathrm{fed}$ & $\begin{array}{l}40 \mathrm{kgN} / \\
\text { fed. }\end{array}$ & mean \\
\hline \multicolumn{14}{|c|}{40 days after sowing } \\
\hline \multicolumn{2}{|c|}{ Control } & 27 & 26.6 & 36.6 & 37 & 3.34 & 3.19 & 3.95 & 3.49 & 3.83 & 1.47 & 1.57 & 2.16 \\
\hline \multirow{2}{*}{\multicolumn{2}{|c|}{$\begin{array}{l}\text { R.legminoserium } \\
\text { R.I.+Azosprillum }\end{array}$}} & 30.3 & 34.3 & 39.6 & 40.3 & 3.81 & 3.61 & 4.35 & 3.92 & 4.29 & 2.17 & 3.01 & 3.12 \\
\hline & & 32.6 & 34.6 & 39 & 40.3 & 3.38 & 3.51 & 4.5 & 3.80 & 4.35 & 2.42 & 3.29 & 3.25 \\
\hline \multirow{3}{*}{\multicolumn{2}{|c|}{$\begin{array}{l}\text { R.I.+B.megaterim } \\
\text { R.I.+B.polymyxa }\end{array}$}} & 31.3 & 34 & 38 & 39.3 & 3.71 & 3.49 & 4.32 & 3.84 & 4.25 & 2.38 & 3.12 & 3.13 \\
\hline & & 35 & 34 & 38 & 40 & 3.73 & 4.0 & 5.05 & 4.26 & 4.81 & 2.82 & 3.4 & 3.68 \\
\hline & & 31.24 & 32.70 & 38.24 & 39.38 & 3.59 & 3.56 & 4.43 & 3.86 & 4.31 & 2.25 & 2.88 & 3.07 \\
\hline \multirow{3}{*}{ LSD. at 0.05} & $\mathrm{~N}$ & \multicolumn{4}{|c|}{1.08} & \multicolumn{4}{|c|}{0.62} & \multicolumn{4}{|c|}{1.04} \\
\hline & Bio & \multirow{2}{*}{\multicolumn{4}{|c|}{$\frac{2.45}{N S}$}} & \multirow{2}{*}{\multicolumn{4}{|c|}{$\mathrm{NS}$}} & \multicolumn{4}{|c|}{ NS } \\
\hline & $\mathrm{N} \times \mathrm{Bi}$ & & & & & \multicolumn{3}{|c|}{ NS } & & \multicolumn{4}{|c|}{ Ns } \\
\hline
\end{tabular}

85 day after sowing

\begin{tabular}{|c|c|c|c|c|c|c|c|c|c|c|c|c|c|}
\hline \\
\hline & & & ant heigl & $\mathrm{t}(\mathrm{Cm})$ & & & Shoot d & t. $(\mathrm{g} / \mathrm{pl}$ & & & Root & (g/plar & \\
\hline \multicolumn{2}{|c|}{ Control } & 103.6 & 121 & 129.3 & 117.97 & 11.8 & 15.85 & 17.47 & 15.04 & 3.51 & 4.65 & 5.04 & 4.40 \\
\hline \multicolumn{2}{|c|}{ Rh.legminoserium } & 133 & 135.3 & 147.6 & 138.63 & 13.86 & 17.02 & 18.8 & 16.56 & 5.48 & 6.42 & 6.44 & 6.11 \\
\hline \multicolumn{2}{|c|}{ R.I.+Azosprillum } & 135.3 & 136.3 & 148 & 139.87 & 13.99 & 18.56 & 20.14 & 17.56 & 6.1 & 7.93 & 8.33 & 7.45 \\
\hline \multirow{2}{*}{\multicolumn{2}{|c|}{$\begin{array}{l}\text { R.I.+B.megaterim } \\
\text { R.I.+B.polymyxa }\end{array}$}} & 131.3 & 133 & 141.6 & 135.30 & 13.53 & 17.21 & 19.18 & 16.64 & 5.95 & 6.58 & 7.7 & 6.74 \\
\hline & & 134.6 & 140.6 & 150.6 & 141.93 & 14.19 & 18.8 & 21.21 & 18.07 & 6.63 & 7.9 & 9.28 & 7.94 \\
\hline & & 127.56 & 133.24 & 143.42 & 134.74 & 13.47 & 17.49 & 19.36 & 16.77 & 5.53 & 6.70 & 7.36 & 6.53 \\
\hline \multirow{3}{*}{ LSD. at 0.05} & $\mathrm{~N}$ & \multirow{2}{*}{\multicolumn{4}{|c|}{$\begin{array}{l}.03 \\
3.42 \\
\end{array}$}} & \multicolumn{4}{|c|}{3.02} & \multicolumn{4}{|c|}{1.13} \\
\hline & Bio & & & & & \multicolumn{4}{|c|}{1.05} & \multicolumn{4}{|c|}{1.66} \\
\hline & $\mathrm{N} \times$ Bio & \multicolumn{4}{|c|}{$\begin{array}{l}3.42 \\
9.17\end{array}$} & \multicolumn{4}{|c|}{3.82} & \multicolumn{4}{|c|}{3.11} \\
\hline
\end{tabular}


Table(6):Effect of rhizobacteria and nitrogen fertilization on faba bean yield and its attributes (two seasons)

\begin{tabular}{|c|c|c|c|c|c|c|c|c|c|c|c|c|c|}
\hline \multirow{2}{*}{ Treatments } & \multirow[t]{2}{*}{$\begin{array}{c}\mathrm{N} \\
\text { level }\end{array}$} & \multicolumn{2}{|c|}{$\begin{array}{c}\text { No. } \\
\text { Branches/plant }\end{array}$} & \multicolumn{2}{|c|}{ No. Pods/plant } & \multicolumn{2}{|c|}{ No. seeds/pod } & \multicolumn{2}{|c|}{ seed indexS2 } & \multicolumn{2}{|c|}{ yield /plant(g) } & \multicolumn{2}{|c|}{ yield /fed (kg) } \\
\hline & & S1 & S2 & S1 & S2 & S1 & S2 & S1 & S2 & S1 & S2 & S1 & S2 \\
\hline Control & 0 & 1.00 & 1.33 & 20.67 & 16.33 & 1.77 & 1.80 & 61.18 & 67.03 & 22.37 & 19.76 & 704.74 & 622.29 \\
\hline Control & 20 & 1.67 & 1.33 & 23.00 & 16.67 & 1.87 & 1.97 & 71.00 & 71.57 & 30.46 & 23.48 & 959.60 & 739.59 \\
\hline \multirow[t]{2}{*}{ Control } & 40 & 2.00 & 1.67 & 24.00 & 17.67 & 1.97 & 2.00 & 73.90 & 74.20 & 34.91 & 26.16 & 1099.66 & 824.05 \\
\hline & & 1.56 & 1.44 & 22.56 & 16.89 & 1.87 & 1.92 & 68.69 & 70.93 & 29.25 & 23.13 & 921.33 & 728.64 \\
\hline R.legminoserium & 0 & 1.33 & 1.67 & 23.00 & 17.67 & 1.83 & 1.93 & 73.20 & 73.87 & 30.88 & 25.34 & 972.64 & 798.32 \\
\hline R.legminoserium & 20 & 2.33 & 2.00 & 25.00 & 20.33 & 2.07 & 2.10 & 75.77 & 76.00 & 39.16 & 32.55 & 1233.57 & 1025.26 \\
\hline \multirow[t]{2}{*}{ R.legminoserium } & 40 & 2.67 & 2.67 & 27.67 & 22.33 & 2.10 & 2.17 & 75.87 & 76.77 & 44.00 & 37.07 & 1386.10 & 1167.86 \\
\hline & & 2.11 & 2.11 & 25.22 & 20.11 & 2.00 & 2.07 & 74.94 & 75.54 & 38.01 & 31.66 & 1197.43 & 997.15 \\
\hline R.I.+Azosprillum & 0 & 1.33 & 2.00 & 23.67 & 18.67 & 2.00 & 1.97 & 72.53 & 72.17 & 34.43 & 26.59 & 1084.40 & 837.53 \\
\hline R.I.+Azosprillum & 20 & 2.33 & 2.67 & 24.33 & 22.33 & 2.00 & 2.07 & 73.70 & 73.23 & 35.79 & 33.81 & 1127.53 & 1065.03 \\
\hline \multirow[t]{2}{*}{ R.I.+Azosprillum } & 40 & 3.00 & 3.33 & 29.33 & 24.33 & 2.13 & 2.23 & 75.47 & 74.53 & 47.32 & 40.46 & 1490.54 & 1274.33 \\
\hline & & 2.22 & 2.67 & 25.78 & 21.78 & 2.04 & 2.09 & 73.90 & 73.31 & 39.18 & 33.62 & 1234.16 & 1058.96 \\
\hline R.I.+B.megaterim & 0 & 1.33 & 1.33 & 23.00 & 18.00 & 1.93 & 1.93 & 73.30 & 74.13 & 32.53 & 25.80 & 1024.83 & 812.74 \\
\hline R.I.+B.megaterim & 20 & 2.00 & 2.33 & 23.67 & 22.67 & 2.20 & 2.20 & 75.67 & 75.50 & 39.25 & 37.59 & 1236.47 & 1184.09 \\
\hline \multirow{2}{*}{ R.I.+B.megaterim } & 40 & 2.67 & 2.33 & 30.33 & 23.67 & 2.27 & 2.27 & 76.50 & 76.73 & 52.55 & 41.13 & 1655.24 & 1295.54 \\
\hline & & 2.00 & 2.00 & 25.67 & 21.44 & 2.13 & 2.13 & 75.16 & 75.46 & 41.44 & 34.84 & 1305.51 & 1097.45 \\
\hline R.I.+B.polymyxa & 0 & 1.67 & 2.00 & 24.33 & 18.67 & 2.17 & 2.00 & 73.20 & 73.97 & 38.62 & 27.59 & 1216.68 & 868.93 \\
\hline R.I.+B.polymyxa & 20 & 2.67 & 2.33 & 26.33 & 23.00 & 2.23 & 2.20 & 76.40 & 77.30 & 44.90 & 39.15 & 1414.34 & 1233.28 \\
\hline \multirow[t]{2}{*}{ R.I.+B.polymyxa } & 40 & 3.33 & 3.33 & 32.00 & 24.67 & 2.53 & 2.43 & 78.30 & 77.97 & 63.41 & 46.81 & 1997.54 & 1474.51 \\
\hline & & 2.56 & 2.56 & 27.56 & 22.11 & 2.31 & 2.21 & 75.97 & 76.41 & 48.98 & 37.85 & 1542.85 & 1192.24 \\
\hline \multirow[t]{3}{*}{ Mean of N } & 0 & 1.33 & 1.67 & 22.93 & 17.87 & 1.94 & 1.93 & 70.68 & 72.23 & 31.77 & 25.01 & 1000.66 & 787.96 \\
\hline & 20 & 2.20 & 2.13 & 24.47 & 21.00 & 2.07 & 2.11 & 74.51 & 74.72 & 37.91 & 33.32 & 1194.30 & 1049.45 \\
\hline & 40 & 2.73 & 2.67 & 28.67 & 22.53 & 2.20 & 2.22 & 76.01 & 76.04 & 48.44 & 38.33 & 1525.82 & 1207.26 \\
\hline \multirow{3}{*}{ LSD, at 0.05} & $\mathbf{N}$ & 0.63 & NS & 2.05 & 2.14 & 0.12 & 0.15 & 2.53 & 2.64 & 5.32 & 6.19 & 93.52 & 87.66 \\
\hline & Bio & 0.38 & 0.36 & 1.32 & 1.43 & NS & NS & 2.27 & 2.19 & 4.87 & 4.92 & 103.24 & 142.16 \\
\hline & $\begin{array}{l}\text { Nx } \\
\text { Bio }\end{array}$ & 0.78 & 0.65 & 1.07 & 2.16 & 0.13 & 0.08 & 5.42 & 3.91 & 6.22 & 2.17 & 132.27 & 88.14 \\
\hline
\end{tabular}

